Esta revista forma parte del acervo de la Biblioteca Jurídica Virtual del Instituto de Investigaciones Jurídicas de la UNAM

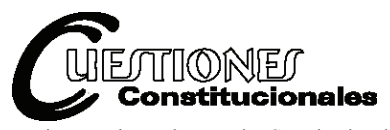

Revista Mexicana de Derecho Constitucional

Núm. 36, enero-junio 2017

\title{
EL CANON EUROPEO E INTERAMERICANO DE LA PRIVACIÓN DEL SUFRAGIO PASIVO
}

\author{
THE EUROPEAN AND INTERAMERICAN CANONS \\ OF THE ELECTIVE RIGHTS DISENFRANCHISMENT
}

\author{
Luis Efrén RÍOS VEGA*
}

RESUMEN: En este trabajo presento, a partir de "casos líderes", los estándares europeo e interamericano que los jueces constitucionales deben emplear para justificar la privación del derecho al sufragio pasivo por violación al pacto de la democracia electoral. Por un lado, se describen los casos europeos que representan el "canon proporcional", mientras que, por la otra, se explicita el "canon categórico" que es propia de la interpretación interamericana. Al final, se propone la fórmula de "ley del miedo electoral" para hacer el test de la privación del sufragio pasivo bajo principios de estricta legalidad y proporcionalidad, de tal manera que sólo se puede explicar la restricción del derecho a ser electo si existe la imperiosa necesidad de evitar o sancionar riesgos reales, graves e inmediatos que ponen en peligro los fines de la democracia electoral.

Palabras clave: muerte cívica, democracia militante, privación del sufragio, derecho a ser electo, ley del miedo electoral, candidaturas peligrosas.
ABSTRACT: In this paper, I present relevant conclusions from an in depth analysis of the leading cases in both the European and Inter American courts, in which constitutional judgers have established relevant positions regarding the justification of the deprivation of the rights to stand as candidates, as a result of a violation of the covenant of electoral democracy. On one hand, European courts have used a "proportional canon", while on the other; a "categorical canon" is better suited for interpretation in the Inter American system. As a conclusion, an eclectic position called "the fear for the electoral effectiveness" is proposed to test deprivation to stand for election, under the strict principles of legality and proportionality. As a result, the right to be elected might only be restricted if there is an urgent need to prevent or punish a serious and immediate risk that threats the purposes of electoral democracy as a whole.

Descriptors: Citizen Death, Militant Democracy, Felony Disenfranchisement, Elective Rights, Electoral Law of Fear, political nominations dangerous.

* Catedrático de Filosofía del derecho, Filosofía política y Teoría de la democracia en la Facultad de Jurisprudencia de la Universidad Autónoma de Coahuila. Director general de la Academia IDH (Saltillo). 
Esta revista forma parte del acervo de la Biblioteca Jurídica Virtual del Instituto de Investigaciones Jurídicas de la UNAM www.juridicas.unam. $\mathrm{mx}$

SuMARIO: I. Premisas. II. El debate constitucional. III. El canon europeo. IV. El canon interamericano. V. Reflexiones finales. VI Tabla de casos.

\section{PREMISAS}

Al final del siglo XX y principios del XXI, la privación de la libertad electoral por quebrantar el pacto social se ha convertido en uno de los problemas más polémicos en las democracias constitucionales. ${ }^{1}$ Presenta una doble cara: por un lado, implica la "lucha por la universalidad del sufragio activo" 2 a favor de las personas que están detenidas o condenadas por un delito $^{3}$ mientras que, por el otro, representa el debate por la "autodefensa de la democracia" ${ }^{4}$ en contra de aquellos que pretenden concurrir a la conformación del gobierno representativo no obstante que representan un "peligro real, grave e inminente" para los fines de la sociedad democrática ("democracia militante"). ${ }^{5}$ En ambos casos, las controversias del sufragio sintetizan la polémica actual de la antigua "muerte civill", ${ }^{6}$ una ficción me-

1 Véase Ríos Vega, Luis Efrén y Spigno, Irene (eds.), La muerte ciudadana en América y Europa. Un debate contemporáneo, México, Tirant lo Blanch, 2016.

2 Reino Unido y Estados Unidos de América son las dos referencias de tradición anglosajona más relevantes que gestaron las ideas liberales de la democracia representativa que, no obstante, presentan en la actualidad la polémica más intensa sobre el "voto de los prisioneros" (prisioner's voting rights), por su larga tradición en la filosófica contractualista.

Véase Ewald, Alec y Rottinghaus, Brandon (eds.), Criminal Disenfranchisement in an International Perspective, Nueva York, Cambridge University Press, 2009.

4 En Europa y América Latina, principalmente, se presentan las principales polémicas de las leyes privativas del "sufragio" (especialmente "pasivo») con motivo de la defensa de la democracia, sobre todo por el contexto político de cada país (dictaduras, justicia transicional y luchas contra el fascismo, racismo, terrorismo, fundamentalismo, delincuencia organizada, etcétera) que plantean el problema de las "candidaturas peligrosas".

5 Véase Kirshner, Alexander S., A Theory of Militant Democracy. The Ethics of Combatting Political Extremism, New Heaven, Yale University Press, 2014; Ellian, Afshin y Molier, Gelijn, The State of Exception an Militan Democracy in a Time of Terror, Dordrecht, Republic of Letters Publishing, 2012; Thiel, Markus (ed.), The Militant Democracy Principle in Modern Democracies, Inglaterra, Ashgate, 2009; Sajó, András (ed.), Militant Democracy, Netherlands, Eleven International Publishing, 2004.

6 Véase "Civil Death Statutes-Medieval Fiction in a Modern World", Harvard Law Review, vol. 50, núm. 6, abril de 1937. 
Esta revista forma parte del acervo de la Biblioteca Jurídica Virtual del Instituto de Investigaciones Jurídicas de la UNAM

dieval que tiene hoy una narración constitucional de normas, contextos y soluciones para explicar la mejor versión de la libertad política en la democracia contemporánea. ${ }^{7}$

Platón inicio el debate en La República con la pregunta ¿quién debe gobernar? John Locke respondió que los criminales no deben gobernar. El "contrato social" que defiende Hobbes, Rousseau y Locke constituye, por tanto, el fundamento de la privación de la ciudadanía como medida preventiva de seguridad. ${ }^{8}$ La versión del sufragio basada en el contrato social de JeanJacques Rousseau (1762) estriba en el derecho a participar en la voluntad general, la ley: "el que obedece la ley, tiene derecho a hacerla". La libertad política de conformar la ley, por ende, tiene un fundamento contractual para asegurar la libertad de todos: "respetar el pacto permite conformarlo". Es decir, "obedecer el pacto explica el derecho a ratificarlo [con el sufragio activo] a través de las elecciones libres y, por ende, modificarlo [con el sufragio pasivo] por medio de la ley en el gobierno representativo". Es la lectura contractual: "el que viola la ley, no tiene derecho a conformarla". Dicho de otra forma: cumplir el pacto es la prestación para recibir la protección e inclusión de la ley como contraprestación. Es decir, "el derecho a conformar el pacto es por el cumplimiento del deber de respetarlo". 9

Esta lectura contractualista - ficción conveniente según Jeremy Waldron- ${ }^{10}$ perdura en el debate actual de la privación del sufragio y explica, asimismo, el paradigma del "constitucionalismo de poderes" del "Estado preventivo militante" que pretende garantizar la libertad de las personas mediante una

7 Véase en Inglaterra la polémica de la sentencia Hirst (2005) del Tribunal Europeo de los Derechos Humanos con el Reporte de la Comisión Mixta sobre el Proyecto de Ley del Voto de los Prisioneros [Draft Voting Eligibility (Prisoners) Bill], Parlamento del Reino Unido, 18 de diciembre de 2013, p. 34, disponible en: http://www.parliament.uk

8 Hull, Elizabeth A., The Disenfranchisement of Ex-Felons, Filadelfia, Temple University Press, 2006, p. 51; Wilkins, Pamela A, "The Mark of Cain. Disenfranchised Felonsand and The Constitucional no man's Land”, Syracuse Law Review, vols. 56 y 85, 2005, p. 109.

9 En el debate del Parlamento Británico del caso Hirst (2005), el legislador David Davis describió esta postura al decir: "If you break the law, you cannot make the law" (House of Commons, Parlamentary Debates, vol. 523, núm. 116, 10 de febrero de 2011, p. 493). (Si quebrantas la ley, no puedes participar en su conformación).

10 Véase el debate de la teoría del contrato social en el Reporte de la Comisión Mixta sobre el Proyecto de Ley del Voto de los Prisioneros [Draft Voting Eligibility (Prisoners) Bill], Parlamento del Reino Unido, 18 de diciembre de 2013, p. 34, disponible en: http:// www.parliament.uk 
Esta revista forma parte del acervo de la Biblioteca Jurídica Virtual del Instituto de Investigaciones Jurídicas de la UNAM

política de restricción cautelar a sus enemigos. En el fondo, la cuestión de la "muerte cívica"11 implica una discusión filosófica sobre la concepción de la democracia (incluyente-excluyente) que prescriba un modelo jurídico con la restricción del sufragio en un contexto político determinado, con sus diferentes variables y matices normativos, a fin de garantizar — en términos de la democracia electoral - la conformación libre de la voluntad popular. ¿Cuál es la relevancia actual de la "muerte cívica"? ${ }^{12}$ Esta figura, ciertamente, tiene su origen en el mundo antiguo. En las antiguas Grecia y Roma, se comenzó a configurar la idea según la cual los quebrantadores de la ley deben ser excluidos del demos mediante la privación del derecho a participar en la polis. Estos orígenes históricos de las leyes privativas de la ciudadanía que se remontan a la construcción tradicional de la ciudadanía republicana del mundo antiguo, se basan en el "estatus de honor" que, por ciertas conductas ofensivas, motivan la privación de derechos cívicos por medio de la atimia (Atenas y Esparta), o la infamia (Roma). En la Inglaterra medieval, posteriormente, se desarrollan las leyes de proscripción que privan al ciudadano-noble de sus derechos de propiedad y hereditarios por la condena de delitos graves. ${ }^{13}$ El mundo medieval, por tanto, desarrolló este tipo de limitaciones a esta "libertad política de los antiguos" mediante las "leyes de proscripción" (outlawry, attainder, civil death) que tenían por objeto declarar a una persona "fuera de la protección de la ley". ${ }^{14}$ En el mundo moderno, finalmente, la figura resistió la evolu-

11 Civiliter mortuus (latín), civil death (inglés), mort civile (francés), morte civile (italiano). He preferido emplear el término "muerte cívica o ciudadana", en lugar de civil, para restringir el concepto por dos razones: 1) la antigua "muerte civil" es el estado de una persona que es privada de sus derechos civiles por considerarla muerta o inexistente por diferentes causas medievales; en cambio, la privación del sufragio — aunque se equipare a la civil death—, en realidad se limita hoy a la condición política — no civil— de las personas; y, 2) conforme a las normas universales, regionales y nacionales, el significado de los "derechos políticos que pertenecen a los ciudadanos", es diferente a los derechos civiles. Luego entonces, resulta más propio circunscribir la "muerte cívica" (del lat. civicus, de civis, ciudadano) a la privación de los derechos políticos por conductas (penalmente o electoralmente relevantes) que son ofensivas al pacto de renovación libre y periódica del gobierno representativo.

12 Véase "Civil Death Statutes-Medieval Fiction in a Modern World", cit., pp. 968977.

13 Pettus, Katherine Irene, Felony Disenfranchisement in America. Historical Origins, Institutional Racism, and Modern Consequences, University of New York Press, 2005, pp. 11-21 y ss.

14 Figler, Bailey, "A Vote of Democracy: Confronting the Racial Aspects of Felon 
Esta revista forma parte del acervo de la Biblioteca Jurídica Virtual del Instituto de Investigaciones Jurídicas de la UNAM

ción del constitucionalismo europeo y americano - no obstante sus fines y orígenes racistas $-{ }^{15}$ porque se mantuvieron vigentes estas restricciones en los ámbitos penal-electoral. Existen así diferentes modelos de privación del sufragio pero con un común denominador: limitar el sufragio, activo o pasivo, o el derecho de asociación política (para conformar y participar en un partido político), por el reproche de una conducta que se considera riesgosa para la democracia según el "derecho electoral de autor, de acto o del enemigo", tres concepciones que según el contenido y alcance del hecho a prohibir fundan la "ley del miedo electoral" por lo que es, por lo que hace o por lo que puede hacer el quebrantador en contra del pacto para renovar de manera libre y auténtica el gobierno representativo.

Desde la antigüedad hasta nuestros días la "muerte cívica" permanece pues una especie de "ley de miedo" (Law of Fear) $)^{16}$ en contra de la "ciudadanía peligrosa". Esta regla privativa de derechos tiene una evolución peculiar en diferentes contextos actuales para desterrar del demos a las personas que, por razones retributivas, preventivas o reguladoras, se consideran indignas de participar en la conformación de la voluntad popular: las llamadas "cadenas o grilletes a la ciudadanía del siglo XXI". ${ }^{17}$ La privación del sufragio constituye, por tanto, una modalidad contemporánea de la antigua "muerte civil" que, sin embargo, permanece en las leyes actuales para proscribir el derecho a la participación política. Por ejemplo, la "muerte cívica" se encuentra hoy en la configuración de leyes privativas de derechos políticos, entre las que destacan las leyes que se fundan por razones "penales"18

Disenfranchisement”, NYU Annual Survey of American Law, vol. 61, núm. 723, 2006, pp. 728 y ss.

15 Manza, Jeff y Uggen Christhoper, Locked Out. Felon Disenfranchisement and American Democracy, Nueva York, Oxford University Press, 2008.

16 Véase Sunstein, Cass R., Leyes de miedo. Más allá del principio de precaución, Madrid, Katz, 2009.

17 Ewald, Alec, "Civil Death: The Ideological Paradox of Criminal Disenfranchisement Law in the United States", Wisconsin Law Review, 2002, pp. 1045-1137.

18 Para el caso europeo, véase la tabla del voto de los prisioneros en los países del Consejo de Europa, en Prisioner's voting rigths, Centro Parlamentario y Constitucional (SN/PC/01764, 16 de octubre de 2013), disponible en: http://www.parliament.uk. Para el caso latinoamericano, véase la tabla de los países de América Latina sobre la privación del sufragio por causa penal, en Amicus Curie de Human Rights Foundation sobre el caso López Mendoza vs. Venezuela, 2011, disponible en: http://www.lahrf.com. Para un caso nacional, véase las leyes de los Estados americanos en Felony Disenfranchisement Laws in The United States, 2013, disponible en: http://sentencingproject.org 
Esta revista forma parte del acervo de la Biblioteca Jurídica Virtual del Instituto de Investigaciones Jurídicas de la UNAM

(disenfranchisement of felons) o por "ilegalización partidista"19 (dissolution of political parties). En el primer caso: $i$ ) el delito $-\mathrm{y}$ la prisión en su caso - es el motivo de la restricción a la ciudadanía: la privación de la libertad personal apareja la privación de la libertad política como consecuencia colateral, obvia y necesaria porque la detención impide el ejercicio del sufragio a la persona confinada; ii) la prohibición de la actividad ilícita de los partidos y sus efectos de continuarlo o sucederlo, por el contrario, explican la limitación a las listas o candidaturas contaminadas - de manera originaria o sobrevenida - para evitar que los quebrantadores de la democracia puedan concurrir a las elecciones libres. Estas problemáticas (violación a la ley penal o de partidos) son la base contemporánea para reconstruir una teoría general de la privación de los derechos electorales que tenga por objeto proteger a la democracia.

Pues bien, el problema estriba en determinar si los quebrantadores de la ley (lawbreakers) pierden, y en qué medida, el derecho a ser tratados como ciudadanos para conformar el pacto representativo (votar y ser votado). Es decir: ¿pierden el derecho a conformar la ley aquellos que la transgreden? O dicho de otra manera: ¿el infractor del pacto pierde en forma automática o proporcional la protección de la "cláusula de igualdad electoral" en la configuración del demos? Existen dos respuestas iniciales:

- R1. La tesis hegemónica defiende la restricción categórica del sufragio por razones historicistas, contractualistas, republicanas, meritocráticas y militantes: no merecen el estatus de honor para gobernar los que no respetan el pacto social. ${ }^{20}$

- R2. La posición contra-hegemónica, por el contrario, sostiene que los grilletes a la libertad política contradicen los principios de igualdad y de no-discriminación del sufragio como derecho fundamental: ${ }^{21}$ la

19 Para el caso europeo, véase Guidelines on Prohibition and Dissolution of Political Parties and Analogous Measures, Comisión de Venecia, 1999, disponible en: http://www. venice.coe.int

20 Véase Clegg, Roger, "Who Should Vote?", Texas Review of Law \& Politics, vol. 6, pp. 160-178; Clegg, Roger et al., "The Bullet and The Ballot? The case for Felon Disenfranchisement Statutes", Journal of Gender, Social Policy \& The Law, vol. 14:1, 2006, pp. 3-26.

21 Véase Ewald, Alec, “An Agenda for Demolition: The Fallacy and the Danger of the Subversive Voting Argument for Felony Disenfranchisement", Columbia Human Rights Law Review, vol. 36, núm. 1, 2004, pp. 109-144. 
Esta revista forma parte del acervo de la Biblioteca Jurídica Virtual del Instituto de Investigaciones Jurídicas de la UNAM

violación a la ley, por sí misma, es insuficiente para negar la posibilidad de gobernar si la pérdida de la ciudadanía resulta ser excesiva, inusual o desproporcional.

¿Cuál es la solución correcta? La posición a favor o en contra depende de una toma de postura sobre la concepción (incluyente o excluyente) de la ciudadanía como derecho fundamental, en contraste con el modelo (fuerte o débil) de defensa de la democracia. Es decir, si para proteger las elecciones libres resulta útil y necesario excluir el derecho a la participación política a aquellos que se califiquen como personas (sin dignidad electoral) porque sus conductas dañan o ponen en riesgo grave a la democracia, la respuesta a la cuestión se decanta por la privación del sufragio, o viceversa. La solución al problema tiene también una explicación de práctica constitucional: una u otra posición depende en gran medida del tipo de escrutinio judicial del principio de la proporcionalidad a la hora de justificar o no la limitación del sufragio. ${ }^{22}$

En consecuencia, la restricción del sufragio por violación al pacto electoral replantea la "cuestión democrática" en la constitución del demos: ¿quién no tiene derecho a elegir o a ser electo por la comisión de una conducta (penal, electoral o antidemocrática) que es relevante prohibir para tutelar los fines de la sociedad democrática? Sin duda, se trata de una pregunta para discutir el contenido, alcance y límites de una de las restricciones con mayor arraigo y tradición en las legislaciones que limitan el sufragio por la violación al pacto social, pero que hoy bajo el discurso de los derechos humanos se pone en duda por la opinión pública, ${ }^{23}$ los movimientos sociales, ${ }^{24}$ la doctrina especializada $^{25} \mathrm{y}$ las corrientes internacionales contemporáneas. ${ }^{26}$

22 Véase la diferente forma de entender el "test de proporcionalidad" en la limitación del sufragio pasivo por condena penal, en los votos concurrentes de Diego García-Sayán y Eduardo Vio Grossi en el caso López Mendoza, 2011.

23 "The Economist", Prisioners: Let them vote, Unsigned Editorial, 31 de octubre de 2009.

24 En los Estados Unidos de América, la cuestión del voto de los criminales ocupa una relevancia actual como lucha ciudadana desde la academia. Para consultar las posiciones a favor y en contra, disponible en: http://felonvoting.procon.org

25 Véase Behrens, Angela, "Voting-Not Quite a Fundamental Right? A Look at Legal and Legislative Challenges to Felon Disfranchisement Laws", Minnesota Law Review, vol. 89, núm 1, 2004, pp. 231-275.

26 Véase Ziegler, Reuven, "Legal Outlier, Again? U.S. Felon Suffrage: Compara- 
Esta revista forma parte del acervo de la Biblioteca Jurídica Virtual del Instituto de Investigaciones Jurídicas de la UNAM

En efecto, la exclusión indebida del sufragio plantea un problema fuerte de legitimidad en torno al grado de inclusividad que debe poseer la "ciudadanía política" para que un sistema electoral se considere democrático. ${ }^{27} \mathrm{La}$ "democracia excluyente", en efecto, constituye una categoría de "democracia imperfecta o defectuosa" que se caracteriza por el déficit de las garantías de los derechos electorales. ${ }^{28}$ Por tal razón, uno de los retos actuales de las democracias que autorizan privar en forma categórica (sin explicar motivadamente la causa legal) el sufragio a los quebrantadores de la ley consiste, justamente, en liberar este tipo de grilletes que se consideren "discriminatorios, crueles, inusuales o desproporcionales". ${ }^{29}$

Esta "muerte ciudadana" desde luego plantea diferentes problemas sobre el por qué, cómo y cuándo se debe restringir la libertad electoral por violar el pacto electoral de la democracia. ${ }^{30}$ La tesis central consiste en explicar, a partir de un modelo de estricta legalidad y proporcionalidad, la restricción del derecho a la "participación política" a aquella persona que configure una conducta electoralmente relevante constitutiva de un "riesgo real, inminente y grave" para los fines esenciales de la "democracia electoral". Es la idea de la "ley del miedo electoral" que configura una garantía de autodefensa de las elecciones libres para tutelar la conformación auténtica del gobierno representativo. ${ }^{31}$

tive and International Human Rights Perspectives", Boston University Internacional Law Journal, vol. 29:197, 2011, pp. 200 y ss.

27 Dahl, Robert, La democracia y sus críticos, trad. de L. Wolfson, Barcelona, Paidós, 1992, pp. 147 y ss.

28 Morlino, Leonardo, Democracias y democratizaciones, México, Cepcom, 2005, p. 258 .

29 Véase Dhami, Mandeep K., "Prisoner Disenfranchisement Policy: a Threat to Democracy?", Analyses of Social Issues and Public Policy, vol. 5, núm. 1, 2005, pp. 235247.

30 El concepto anglosajón disenfranchisement (privación del sufragio) puede comprender no sólo la causa penal (felony) sino también la causa electoral u otras similares que impliquen restricciones del sufragio (activo o pasivo) por conductas ofensivas a la democracia (Militant Democracy). Por tanto, la privación de derechos políticos por causa electoral (electoral disenfranchisement) es un vocablo que es útil para identificar en la democracia una diferente categoría de "leyes del miedo" de Cass Sunstein (Laws of Fears), la del "miedo electoral". Esta denominación, a mi juicio, comprende de una manera más precisa, completa y amplia —en el lenguaje constitucional— los casos, problemas y soluciones de la privación del sufragio por violación al pacto social.

31 Véase Ríos Vega, Luis Efrén, La privación del sufragio. El debate contemporáneo en México, México, Tirant lo Blanch (en prensa). 
En este trabajo presento el debate de la privación del sufragio pasivo. Describiré los modelos conceptuales que funcionan, según los casos líderes europeos e interamericanos, para justificar la suspensión del derecho a ser electo de las personas que representan un daño o peligro grave e inminente para la democracia. Es la privación de los derechos políticos fundamentales por razones de peligrosidad: restringir el derecho a la participación política por violación al pacto democrático en el Estado constitucional de derecho. En efecto, es la idea de poner "grilletes a la ciudadanía" por conductas relevantes que afectan el sufragio como principio fundamental del gobierno representativo. El problema, por tanto, consiste en determinar por qué, cuándo y cómo es válido restringir la libertad electoral de estas clases peligrosas para evitar la contaminación inaceptable en la conformación de la voluntad del Estado. Me interesa describir sobre todo los estándares de solución a los problemas que se pueden explicar a partir de los casos. Por un lado, el "canon de Estrasburgo" se acerca más a la "concepción proporcional" de la muerte cívica: la causa idónea, útil y necesaria para limitar la libertad electoral debe individualizarse de manera estricta y proporcional para proteger los fines de la sociedad democrática. Por el contrario, el "canon de San José" es una lectura más "categórica": la causa legal de la restricción del sufragio pasivo opera de manera automática para proteger en forma directa el orden constitucional. No obstante la diferente forma de aplicar el principio de proporcionalidad en ambos sistema de protección de los derechos humanos existen, por supuesto, algunos criterios interpretativos similares que pueden explicar la configuración de lo que llamo la "ley del miedo electoral". Al final, propondré una fórmula de solución constitucional que puede ser aceptable tanto para el sistema europeo como para el interamericano.

\section{EL DEBATE CONSTITUCIONAL}

En la actualidad, el derecho a ser electo presenta dilemas, retos y desafíos en la configuración de las "candidaturas peligrosas"32 que plantea la disyuntiva de permitir o prohibir el derecho a presentarse a las elecciones a ciertos perfiles que pueden representar daños o riesgos graves para la

32 Véase Ríos Vega, Luis Efrén, Sufragio pasivo, inmunidad parlamentaria y delincuencia organizada. El caso Godoy, México, Porrúa, 2010. 
Esta revista forma parte del acervo de la Biblioteca Jurídica Virtual del Instituto de Investigaciones Jurídicas de la UNAM

conformación libre del gobierno. Cada país tiene riesgos a evitar y parece, desde luego, que muchos Estados nacionales tienen buenas razones para limitar, en forma estricta y limitativamente, la ciudadanía política en casos excepcionales que se explican de acuerdo a ciertos contextos políticos de justicia transicional, inseguridad, violencia o miedo político.

Pues bien, el debate actual de las "candidaturas peligrosas" presenta "casos límite" 33 para la democracia entre las que destacan tres:

1. El dilema de la (i)legitimidad de las democracias cuando se utiliza la figura legal de la privación del sufragio como instrumento - abusivo o fraudulento- de descalificación política en contra de los adversarios $^{34}$ (cuestión de la persecución política).

2. La problemática de la (i)legitimidad de la representación política cuando la hipótesis del "sufragio subversivo" (subversive-voting) o la "pureza en las urnas" (purity of the ballot box), pueden ser una realidad porque en los gobiernos representativos permea el vínculo con el crimen organizado ${ }^{35}$ (cuestión de la democracia militante).

3. El problema de las elecciones libres cuando la restricción (in)debida del sufragio o su reconocimiento ilegal pone en tela de juicio la autenticidad del voto (la cuestión de la nulidad electoral).

33 En la doctrina de los casos judiciales, los "casos límite o dudosos" son los que se encuentran en la zona gris o zona de penumbra de la aplicación de algún término ("Borderline case", The Oxford Dictionary of Philosophy, Oxford University Press, 2005). Los casos de "candidaturas peligrosas" presentan una constante común: tienen dos o más concepciones polémicas que pueden justificar la interpretación de la norma a aplicar de manera dudosa.

34 El caso interamericano López Mendoza, 2011, revela, por una parte, la cuestión de la descalificación del adversario, pero también, por la otra, se plantea el margen de apreciación nacional que las leyes privativas del sufragio pueden llegar a tener fuera de la categoría de la "condena, por juez competente, en proceso penal": la inhabilitación del sufragio por la vía administrativa.

35 En la India, el 31\% de los parlamentarios enfrentaron cargos criminales, entre los cuales el 14\% son de naturaleza grave, lo cual ha generado que la Corte Suprema de India, en julio del 2013, haya pronunciado fallos restrictivos del sufragio pasivo a las personas en prisión (véase reportes de observación electoral en http://adrindia.org. 
Esta revista forma parte del acervo de la Biblioteca Jurídica Virtual del Instituto de Investigaciones Jurídicas de la UNAM

Me centraré en las dos cuestiones. ${ }^{36}$ En Argentina, ${ }^{37}$ por ejemplo, el debate su ubica en los presuntos delincuentes por crímenes de lesa humanidad. ${ }^{38}$ En Colombia, ${ }^{39}$ la parapolítica presenta el problema del maridaje de los congresistas con los grupos paramilitares, lo cual ha planteado el debate de reformas legales para suspender derechos políticos por vinculación con los grupos de la delincuencia organizada. En España, las candidaturas proterroristas implican casos en donde se limitan los derechos políticos a personas relacionadas con el partido ilegalizado para evitar listas electorales contaminadas..$^{40}$ En Guatemala, el problema se sitúa en los golpistas o dictadores que quieren regresar al poder. ${ }^{41}$ En Italia, por el contrario, la cuestión se presenta en los presuntos mafiosos que son señalados en procedimientos de investigación en contra de la mafia. ${ }^{42}$ En Turquía, las candidaturas fundamentalistas representa un problema para la laicidad que socaba al Estado constitucional. ${ }^{43}$ En fin cada país, al final de cuentas, tiene sus razones contextuales para proponer la limitación de la ciudadanía electoral por causas penales o antidemocráticas, pero en todo caso deben justificarse plenamente las causas de restricción en el marco del discurso de los derechos.

36 Para la cuestión de la nulidad de la elección por privación del sufragio, véase Pujadas Tortosa, Virginia Flores, Suspensión del sufragio pasivo y validez de los comicios (a partir del caso Aguascalientes); Flores, Imer B., La suspensión de los derechos políticos y su impacto en la invalidez de la elección. A propósito del déjà vu y flash-forward del caso Aguascalientes, 2010; Ríos Vega, Luis Efrén, "La privación del sufragio como causal de nulidad", en Ríos Vega, Luis Efrén (ed.), Debates actuales del federalismo electoral. Una visión regional, México, Tirant lo Blanch, 2016.

37 Véase Carnota, Walter F. y Cesano, José Daniel, El voto de los presos, Buenos Aires, Ediar, 2007.

38 Véase casos Bussi (2007) y Patti (2008) resueltos por la Corte Suprema de la Justicia de Argentina, en donde se permitió acceder y mantener el cargo público representativo a presuntos dictadores, no obstante la acusación en su contra de delitos de lesa humanidad, lo cual ha planteado el debate de una reforma constitucional para inhabilitar los derechos políticos a los presuntos autores de actos de fuerza contra el sistema democrático. La razón, desde la perspectiva de la justicia transicional, es obvia: muchos dictadores no pueden ser juzgados porque siguen en el poder, por lo que una regla que se discute es justamente su inhabilitación política.

39 “La «parapolítica» ensucia Colombia”, El País, 1o. de junio de 2008.

40 Véase casos ANV (2007); Iniciativa internacionalista-La solidaridad entre los pueblos (2009).

41 Véase Ríos Montt (1993).

42 Véase Labita (2004); Vito Sante Santero (2000).

43 Véase Sobaci (2007). 
Esta revista forma parte del acervo de la Biblioteca Jurídica Virtual del Instituto de Investigaciones Jurídicas de la UNAM

En la privación del sufragio pasivo, la "causa antidemocrática" implica pues una forma de "suspensión preventiva": no se requiere, por ejemplo, un juicio penal a los golpistas que ponen en riesgo el orden democrático. Basta que existan pruebas que indiquen el riesgo de quebrantar el orden constitucional para aplicar en forma preventiva la privación de los derechos electorales. Los nazis en Alemania, ${ }^{44}$ los fascistas en Italia, ${ }^{45}$ los terroristas en España, ${ }^{46}$ los antinacionalistas en Israel, ${ }^{47}$ los fundamentalistas en Turquía, ${ }^{48}$ en fin, son casos en donde se priva sobre todo el derecho a conformar un partido por los fines y actividades antidemocráticas graves y reiteradas, lo cual genera la disolución de ese tipo de partidos ilegales que puede dar lugar a la suspensión de derechos políticos: inhabilitar los cargos parlamentarios, anular las listas contaminadas, principalmente.

Pues bien, la polémica constitucional tiene un punto de partida. Es una "cuestión de derechos" que el juez ha ido resolviendo en demandas concretas: en realidad no debe ser una cuestión de crear nuevos derechos en forma retroactiva, sino de garantizarlos. El juez, al tratar un problema de restricción del sufragio debe entender que hay espacios propios del legislador democrático que debe respetar conforme al sistema constitucional de que se trate, pero también debe entender su rol de garantizar — como guardián de los derechos - las condiciones necesarias para asegurar que la libertad política no pueda ni deba ser restringida de manera arbitraria. Esta es una de las cuestiones más controvertidas de la filosofía constitucional (objeción contra-mayoritaria) y que, con sus perfiles propios, aparece en el debate de la privación del sufragio: cada comunidad política — en el ámbito del legislador democrático - tiene derecho a reflexionar libremente el alcance del sufragio a los quebrantadores de la ley, a partir de ciertas pautas (conceptuales y contextuales) que impidan que la mayoría restrinja de manera arbitraria la libertad política. El problema radica en delimitar esas esferas propias de los derechos de la minoría y de los poderes de la mayoría.

En tal sentido, el tema plantea problemas constitucionales que se delimitan sobre la aplicación de las reglas siguientes:

44 Véase Thiel, Markus, "Germany”, en Thiel, Markus (ed.), The Militant Democracy Principle in Modern Democracies, Inglaterra, Ashgate, 2009, pp. 109 y ss.

45 Véase Ceccanti, Stefano y Clementi, Francesco, "Italy", en Thiel, Markus (ed.), The Militant Democracy Principle in Modern Democracies, cit., pp. 209 y ss.

46 Véase Vidal Prado, Carlos, "Spain", ibidem, pp. 243 y ss.

47 Véase Neuberger, Benyamin, "Israel", ibidem, pp. 183y ss.

48 Véase Emrah Oder, Bertil, “Turkey”, ididem, pp. 263y ss. 
Esta revista forma parte del acervo de la Biblioteca Jurídica Virtual del Instituto de Investigaciones Jurídicas de la UNAM

- R1. "Cláusulas de igualdad y no discriminación". ¿Los quebrantadores de la ley son iguales, para efectos electorales, a los que respetan la voluntad general? ¿El infractor de la democracia cuenta igual que el ciudadano libre de responsabilidad? ¿Existe discriminación (in)justificada en la privación del sufragio? Un punto de partida a discutir: como personas sí, valen lo mismo y la condición de infractor por sí misma es insuficiente para que como persona tenga menor valor electoral; pero como sujetos de deberes y responsabilidades en un pacto social pueden llegar a discutirse los tratos restrictivos según la valoración que tenga el (in)cumplimiento de la ley que cada quien decide conforme a su propia autonomía personal. Es decir: el infractor del pacto es igual a quien no lo es como persona (principio de igual valor), sí, pero su conducta ilegal puede dar lugar a restricciones diferenciadas por su falta cometida (principio de trato diferente), siempre que no constituya causa suficiente de discriminación ilegal.

- R2. "Cláusula de la proporcionalidad". El derecho a la ciudadanía política no es absoluto, pero sus restricciones tampoco. El derecho a elegir (sufragio activo) y a ser electo (sufragio pasivo) se limita por situaciones que deben constituir "motivos idóneos, suficientes y justificados". O dicho de otra manera: cualquier restricción al sufragio como derecho fundamental plantea el debate de la "causa debida": a nadie se le puede privar el sufragio sin causa que lo justifique de manera proporcional. ${ }^{49} \mathrm{La}$ "cláusula de restricción debida", por ende, debe sujetarse a ciertas condiciones para limitar el sufragio: ley "previa, legítima y necesaria" para proteger de manera proporcional la sociedad democrática. Este problema constitucional plantea, a partir del "test de la proporcionalidad", dos dimensiones: a) la "proporcionalidad general” que como apreciación política realiza el legislador para determinar la configuración legítima de la restricción a la conducta a prohibir: las categorías de "excesiva, cruel o

49 El "test de proporcionalidad" para privar el sufragio por un delito es un argumento clave que desde el caso Sauvé hasta la doctrina tanto de la Corte IDH como la Corte EDH, se ha venido desarrollando en la interacción judicial de la mayoría de las cortes constitucionales. La doctrina judicial de los sistemas interamericano y europeo de derechos humanos no niegan la posibilidad de que el Estado constitucional pueda privar el sufragio por la comisión de un delito u ofensa democrática, sino que el problema es demostrar los motivos idóneos, útiles y necesarios para la protección de la sociedad democrática. 
Esta revista forma parte del acervo de la Biblioteca Jurídica Virtual del Instituto de Investigaciones Jurídicas de la UNAM

inusitada" según el escrutinio (penal o electoral) son las referencias del test a analizar; y, b) la "proporcionalidad concreta" que es el juicio que el juez realiza en el caso concreto para explicar la motivación individualizada de la causa legal de la restricción, a partir del principio de la proporcionalidad que se articula con el "test de la ley del miedo electoral".

- R3. "Cláusula del garantismo". Las personas privadas de la libertad enfrentan el "dilema del sufragio por la prisión" que se plantea como hecho incidental o constitucional. Las restricciones penales a la libertad política delimitan a la prisión como una cuestión incidental (infortunio de la vida que no debe resolverse por los jueces), o como una cuestión garantista (técnica que los jueces deben aplicar para remover los obstáculos que impiden ejercer los derechos electorales). En cualquier caso el voto de los prisioneros describe un problema de "garantías a elaborar" (para facilitar el ejercicio del sufragio activo en las prisiones) $)^{50}$ o de "cargas inaceptables e irremovibles" (porque la situación de detención es un hecho incidental que impide votar como consecuencia necesaria de la prisión). El sufragio pasivo, por otro lado, presenta el mismo dilema pero con diferentes variables por la naturaleza individual del contenido esencial del derecho a ejercer: solo una persona es la que ejerce la posibilidad de ser electa, mientras que la dimensión colectiva del sufragio activo es más universal, todos eligen, unos son electos. Las preguntas, por tanto, son: ¿poder votar desde la cárcel?, ¿poder votar en libertad provisional?, ¿poder votar en situación de rehabilitación?, ¿poder hacer campaña electoral desde prisión?, ¿poder tomar protesta del cargo desde la prisión?, ¿poder ejercer la función representativa desde la prisión? ${ }^{51}$ En fin, el sufragio activo - por su esencia universal e incluyente-

50 En muchos sistemas legales el voto de las personas en prisión presenta restricciones materiales o administrativas derivadas de la prisión: son personas condenadas por delitos que no merecen la privación del sufragio, pero que por su condición de detención no pueden registrarse en el padrón electoral para poder votar (Inglaterra), no pueden sufragar por correspondencia por no estar en las causales de la ley (Estados Unidos), o en general, no existen medidas apropiadas para facilitar el ejercicio del sufragio en la prisión (Argentina). Son personas que tienen derecho al voto, pero que no pueden ejercerlo por su condición de prisionero. ¿Se deben remover o no esos obstáculos? Ese es el problema.

51 El caso Morrissey plantea el problema de ser legislador en el día y prisionero en la noche, véase http://ballotpedia.org/Joseph_Morrissey 
pareciera no generar tantas modalidades diferenciadas sobre la justificación del sufragio de los presos (se puede votar desde la cárcel con medidas adecuadas), pero sí en cuanto a su efectividad: la desproporcionalidad de operar derechos políticos a unos con cargas excesivas para todos. El sufragio pasivo, en cambio, plantea situaciones que pueden llegar a ser incompatibles con el derecho a ejercer: permitir el desempeño de un cargo político desde la cárcel, sin posibilidad real de representar a la comunidad. Estos son los perfiles del debate.

En consecuencia, la cuestión constitucional plantea una discusión más fina. Si la lesión al pacto de la democracia que puede producir el delito o infracción electoral, es motivo idóneo, suficiente y necesario para restringir - en forma categórica o proporcional-, el sufragio de las personas. En efecto, el acto lesivo (o peligroso) a la democracia es una causa legal que, en mayor o menor medida, se regula por las leyes privativas del sufragio. No todos tienen derecho a sufragar en la democracia: a algunos se les limita por violar la ley según el sistema constitucional que funciona, según cada modelo de "muerte ciudadana", para prohibir las conductas que constituyen un daño o peligro para la democracia. O sea, el problema constitucional consiste en determinar: ¿cuándo y cómo es razonable privar, de manera preventiva, proporcional y en situaciones excepcionales, el derecho a gobernar? ¿Cuándo y cómo, por tanto, se acredita la "prueba del daño o peligro electoral"?

Por lo tanto, la ley de privación del sufragio (o ley del miedo electoral) plantea entonces discutir si la democracia electoral tiene derecho a defenderse a sí misma mediante la exclusión preventiva de los quebrantadores del pacto, a fin de que no participen en el proceso electoral porque, en razón de sus ofensas o riesgos, ponen en peligro la celebración de comicios libres y auténticos que conforman el "gobierno representativo". Consecuentemente: la "muerte ciudadana" en el siglo XXI implica tanto una cuestión restrictiva como protectora de la democracia: no se trata nada más de explicar la privación del sufragio a las personas porque cometieron una conducta antidemocrática, o sólo un delito sancionado con prisión o porque están privados de su libertad por la duración de la pena, sino sobre todo porque ese delito $u$ ofensa merece (o no) en forma individualizada o automática la restricción del sufragio (como pena, medida de seguridad o restricción electoral) para defender la cláusula de la sociedad democrática. 
Esta revista forma parte del acervo de la Biblioteca Jurídica Virtual del Instituto de Investigaciones Jurídicas de la UNAM

En suma, la polémica constitucional sintetiza tres referencias a debatir en la privación del sufragio: a) motivos (por qué), b) fines (para qué) y c) medios (cómo), tres preguntas que, sin duda, pretenden resolver la idea de aceptar, rechazar o matizar la "ley del miedo electoral". Ese es el debate.

\section{EL CANON EUROPEO}

\section{El caso Ždanoka}

¿El ser parte de un partido comunista que alteró el orden constitucional es razón suficiente para limitar el sufragio pasivo en futuras elecciones democráticas? Las restricciones a los derechos políticos de las llamadas clases peligrosas pueden obedecer también a razones ideológicas: criminalizar, por sedición, al disidente comunista para evitar su participación en el gobierno en los términos de la "doctrina de la conspiración". En la etapa de la guerra fría esto fue recurrente en los Estados Unidos. En Europa, de igual forma, las purgas comunistas son comunes después de la Segunda Guerra Mundial. Existen, por ejemplo, polémicas en donde aún se restringen derechos políticos por haber pertenecido a partidos comunistas que participaron, diez años atrás, en golpes de Estado. En el caso Adamsons (2008), el Tribunal Europeo de los Derechos Humanos sostuvo que los límites al sufragio pasivo por pertenencia partidista pudieran ser entendibles inmediatamente después de ganada la independencia en Letonia, pero si las causas de riesgo no se demuestran, se puede perder la explicación de las mismas con el paso del tiempo. Ergo: una mera sospecha general y abstracta sobre un grupo de personas es, por sí misma, insuficiente para justificar las restricciones al sufragio.

El caso Ždanoka (2006) plantea, por el contrario, un tipo de escrutinio más débil en lo que corresponde al derecho de sufragio pasivo para entender las restricciones por razones pasadas. Veamos los hechos relevantes. Tatiana Ždanoka era miembro del Partido Comunista de Letonia desde 1971. Como tal llegó a ocupar cargos políticos. ${ }^{52}$ Producida la independencia de

52 Tania Ždanoka se afilió en 1971 al Partido Comunista y fue elegida, en las primeras elecciones bajo el régimen soviético, como miembro del Soviet Supremo de la República Socialista Soviética de Letonia. En el plano partidista, Ždanoka fue seleccionada para participar en el Comité Central, posición que ocupó hasta la disolución del partido en agosto de 1991. 
Esta revista forma parte del acervo de la Biblioteca Jurídica Virtual del Instituto de Investigaciones Jurídicas de la UNAM

Letonia respecto de la Unión Soviética, en 1990, la organización del Partido Comunista letón protagonizó dos intentos de golpe de Estado tratando de derribar al gobierno de Letonia y reintegrar el país a la Unión Soviética. Por su conducta golpista el Partido Comunista fue declarado ilegal y disuelto por el Tribunal Constitucional de la República de Letonia, con lo cual se ordenó el cese de sus actividades políticas. En posteriores leyes electorales, municipales y parlamentarias, además, se declaró la inelegibilidad de las personas que hubieran participado activamente en el Partido Comunista Letón después del 13 de enero de 1991, estableciendo un procedimiento judicial para llevar a cabo esta comprobación. El Parlamento letón, por su parte, aprobó en 1995 la Ley de Elecciones Parlamentarias, que en su artículo 5o. establece la inelegibilidad de todas aquellas personas que hubieran participado en determinadas organizaciones, vinculadas a los intentos del golpe de Estado producidos en 1991. La señora Ždanoka, por tanto, se presentó como candidata a las elecciones parlamentarias de 2002..$^{53}$ El órgano encargado de la admisión de las listas electorales, la Comisión Central Electoral, acordó la inelegibilidad de aquélla como candidata a las elecciones. El asunto llegó a la justicia europea de los derechos humanos.

En un primer momento, el Tribunal EDH, actuando en Sala, dijo que si bien podía aceptarse como legítimo la exclusión temporal en las contiendas electorales a los líderes del antiguo régimen, particularmente durante la fase de consolidación de la democracia en Letonia, transcurrido cierto tiempo se hacía necesario un examen más pormenorizado de las circunstancias de cada caso para justificar la inelegibilidad. Luego, pasados diez años desde los intentos del golpe de Estado, el examen individualizado se hacía aún más necesario. La Sala del Tribunal EDH concluyó que la inelegibilidad había vulnerado el derecho a concurrir como candidata. Frente a esta sen-

53 Unos datos previos. Tania Ždanoka pudo participar en las elecciones municipales de 1997 y ser elegida. En las elecciones parlamentarias de 1998 también participó, pero se llevó a cabo una investigación sobre su participación en el Partido Comunista. Se comprobó su activa participación en las actividades del partido al permanecer en su cargo interno del partido hasta la disolución del mismo en 1991. Como consecuencia de esta investigación, fue inhabilitada electoralmente y perdió su escaño como miembro del Consejo Municipal de Riga. En las elecciones parlamentarias de 2002, vuelve a presentarse en una lista uninominal que fue anulada, aplicando la decisión judicial que establecía su inelegibilidad. Como la ley letona que regula las elecciones al Parlamento Europeo no contiene una cláusula de inelegibilidad por haber pertenecido al Partido Comunista Letón, pudo concurrir y ser elegida como europarlamentaria en 2004. 
Esta revista forma parte del acervo de la Biblioteca Jurídica Virtual del Instituto de Investigaciones Jurídicas de la UNAM

tencia, el gobierno de Letonia recurrió el caso ante la Gran Sala del TEDH, la cual revocó la decisión.

En primer lugar, la Gran Sala subrayó la diferencia entre los derechos de sufragio activo y pasivo, por cuanto, respecto de este último, resulta legítimo exigir mayores condiciones de restricción a la hora de interpretar las inelegibilidades, debido a las mayores responsabilidades derivadas del cargo. El Tribunal EDH, por tanto, aceptó que las limitaciones al derecho a ser votado pueden tener una lista abierta, no tasada, de las que resulten "necesarias en una sociedad democrática". Por tanto, se acudió a la necesidad de una mayor individualización de la conducta de los individuos afectados por la prohibición de concurrir a las elecciones, en virtud de su participación en acontecimientos que hubieran puesto en peligro el sistema democrático. El análisis más abierto y menos estricto de la suspensión de derechos políticos llevó, así, a la conclusión de la no-violación de los derechos de ser votada de Tatiana Ždanoka. El Tribunal EDH sostuvo que este tipo de restricciones al sufragio pasivo no establecen una diferenciación de trato basada en las convicciones políticas del individuo, sino que restringe los derechos políticos por una conducta precedente que pone en riesgo el sistema electoral: haber actuado contra el restablecimiento democrático después del 13 de enero de 1991, con lo cual las restricciones funcionaron en el caso para proteger el orden democrático, la seguridad nacional y la integridad territorial de Letonia.

En definitiva, la forma de interpretar las restricciones en el caso de las clases peligrosas que ponen en riesgo la estabilidad del orden democrático, plantea el problema de una metodología de interpretación más amplia: un escrutinio débil a la hora de defender la aplicación favorable de los derechos humanos para sustituirlo por el "test de peligrosidad".

\section{El caso Sobaci}

¿Es válido permitir candidaturas fundamentalistas en un Estado laico? En el caso Refah Partisi (2001) se prohibió a sus líderes de dicho partido ocupar puestos importantes durante un plazo de cinco años por la ilegalización de dicho partido. ${ }^{54}$ En efecto, el Tribunal Constitucional de Turquía

54 Este partido fue fundado en 1983 y en las elecciones de 1995 llegó a tener 158 escaños de 450 de la Asamblea Nacional hasta convertirse en el primer partido de ese país, con lo cual logró formar un gobierno de coalición en 1996. 
Esta revista forma parte del acervo de la Biblioteca Jurídica Virtual del Instituto de Investigaciones Jurídicas de la UNAM

en 1988 ordenó la disolución por estimar que el Refah era el centro de actividades contrarias al principio de laicidad (independencia de los asuntos públicos en relación con los religiosos) que defiende el texto fundamental del país otomano. ${ }^{55}$ Esta sentencia fue a su vez confirmada por la Tribunal EDH. En ella se dijo que la Convención Europea de los Derechos Humanos no podía privar a las autoridades de un Estado democrático a proteger sus instituciones. Un partido político, aclaró, puede promover cambios en las leyes o en las propias estructuras constitucionales del Estado democrático, pero siempre que respete dos condiciones imprescindibles: utilizar medios legales y democráticos y perseguir fines u objetivos compatibles con esos principios básicos. Específicamente, el Tribunal EDH señaló que no se puede invocar la protección del derecho a la libre asociación si los líderes del partido en cuestión incitan a la violencia o defienden un proyecto orientado a la destrucción de la propia democracia. Por lo tanto, todos los grupos e individuos deben aceptar algunas limitaciones en sus derechos, para asegurar la estabilidad y la seguridad del Estado. El Tribunal EDH insistió en que todos estos conceptos deben aplicarse de manera muy estricta, con pruebas muy convincentes y apremiantes y que, en consecuencia, los Estados tienen un límite muy estrecho de apreciación.

En el caso Sobaci (2007), por el contrario, el Tribunal EDH en la línea estricta de interpretación declaró desproporcional la medida de restringir el derecho a ser electo por vinculación de un partido ilegal. En efecto, el 18 de abril de 1999 fue electo Bekir Sobaci como miembro de la Gran Asamblea Nacional de Turquía en virtud de la lista presentada por el Fazilet Partisi. El 7 de mayo de 1999, el abogado general de la República ante la Corte de Casación apeló ante el Tribunal Constitucional de Turquía la acción de disolución legal del Fazilet, basándose en que se había convertido en un centro de actividades contrarias al principio del secularismo y eso era la continuidad del Refah Partisi, previamente disuelto. Pero también se pidió

55 Las declaraciones públicas y actuaciones que fueron materia de la disolución partidista fueron: discursos de sus líderes que defendían el velo islámico en escuelas y oficinas públicas, propuestas de reformas constitucionales para abolir el Estado laico, la discusión de hacerlo en forma violenta y llamados a la Jihad para instaurar la supremacía del Corán y el régimen teocrático, visitas a personas detenidas por hacer apología de grupos terroristas islámicos internacionales, etcétera (García Roca, J., "La problemática disolución del Partido de la Prosperidad ante el Tribunal Europeo de Derechos Humanos: Estado constitucional y control de las actuaciones de partidos fundamentalistas", Revista Española de Derecho Constitucional, año 22, núm 64, mayo-agosto de 2002, p. 300). 
la revocación del mandato parlamentario para todos los líderes y miembros de Fazilet, así como la prohibición para ellos de ser miembros fundadores, miembros, oficiales o interventores a otro partido político por un periodo de cinco años. La Corte Constitucional de Turquía observó que el Fazilet había basado su programa político en el tema del uso de los velos islámicos en escuelas e instituciones públicas para infringir las libertades por el acoso fundamentalista, con lo cual violaban el principio laico. Se dijo que esos líderes incitaron a la gente al odio y a la hostilidad contra autoridades públicas, ocasionando disturbios en el orden público. Bekir Sobaci, no obstante, acude al Tribunal EDH porque estima que la revocación de su mandato parlamentario seguido de la disolución del Fazilet, así como su inelegibilidad han violado su derecho a la libertad de la expresión: las restricciones a él impuestas, alega, que no fueron justificadas, ni proporcionales a la intención u objetivo perseguido con sus acciones de protesta por el velo islámico, lo cual es innecesario en una sociedad democrática por impedirse la oportunidad de emprender la acción política por cinco años.

El Tribunal EDH le da la razón: sostiene que debe asegurarse de que las condiciones a las cuales están sujetos el derecho a ser electo, no deben reducir la libertad política hasta el punto de excluir su sustancia y privarlos de su eficacia, con lo cual toda condición para ser votado que no tenga una intención legítima y los medios empleados revelen desproporción, deben declararse ilegítimas. Es decir: ninguna restricción debe obstruir la expresión libre del pueblo en la elección de la legislatura, so riesgo de frustrar la integridad y eficacia de un proceso electoral dirigido a la voluntad popular con el sufragio universal. Por lo tanto, el Tribunal EDH concluye que la descalificación del mandato parlamentario del quejoso no es proporcional a las intenciones legítimas perseguidas; consecuentemente, la inelegibilidad de Sobaci vulnera la sustancia misma del derecho del aspirante de ser elegido y de ejercitar su mandato, así como el poder soberano del electorado.

En suma, los fundamentalistas han dado origen a la disolución de un partido por los actos públicos y notorios de sus liderazgos políticos más importantes que promueven la vulneración del principio del laicismo, pero al mismo tiempo las inhabilitaciones al derecho a ser votado que no son proporcionales ni justificadas en un caso concreto deben quedar eliminadas para permitir, por más peligrosa que sea la libertad de ese fundamentalismo, su libre participación política. 
Esta revista forma parte del acervo de la Biblioteca Jurídica Virtual del Instituto de Investigaciones Jurídicas de la UNAM

\section{EL CANON INTERAMERICANO}

\section{El caso Ríos Montt}

En América Latina, por su pasado dictatorial e inestabilidad política es frecuente constatar que las leyes nacionales impidan a los rebeldes, dictadores, golpistas o represores que causaron lesiones graves a los derechos humanos, el ejercicio libre de sus derechos políticos para ser electos en una elección democrática.

En Ríos Montt (1993), la Comisión Interamericana de los Derechos Humanos validó la prohibición a ser electo como presidente a un militar que había participado en la alteración del orden constitucional en Guatemala. ${ }^{56}$ En la democracia el golpista padece la muerte ciudadana. Me interesa aquí describir el caso Ríos Montt. Los hechos son los siguientes. José Efraín Ríos Montt presentó una queja contra el gobierno de Guatemala por declarar inadmisible su candidatura a la Presidencia de dicha República. El 23 de marzo de 1982, Ríos Montt fue llamado a presidir el gobierno de facto establecido por los militares golpistas, pero el 8 de agosto de 1983 por otro golpe militar fue separado del cargo que ejercía como Presidente de la República, asumiéndolo su Ministro de la Defensa, con lo cual desde momento no fue molestado ni acusado o sometido a proceso alguno por los delitos del orden constitucional. Incluso, el nuevo jefe del gobierno golpista dictó un decreto de amnistía que fue considerado válido y vigente por la Asamblea Constituyente de 1985, por lo que Ríos Montt se acogió a los beneficios de esa amnistía para participar en el proceso electoral de 1990. Por tal razón, Ríos Montt fue postulado por varios partidos a la Presidencia; las autoridades electorales, empero, se negaron a inscribir dicha candidatura en virtud de que la Corte de Constitucionalidad opinó que la prohibición prevista en la Constitución de Guatemala de 1986 para impedir el acceso a la Presidencia de la República, entre otros, a quienes como consecuencia de un golpe de Estado asumiera la Jefatura de Gobierno, resultaba categórica y permanente. ${ }^{57}$

56 En 2006, la Audiencia Nacional de España solicitó a la justicia guatemalteca la captura con fines de extradición de José Efraín Ríos Montt, tras una denuncia de Rigoberta Menchú Tum, por el delito de genocidio.

57 El artículo 186 de la Constitución de Guatemala dice que no podrán optar al cargo de presidente de la República: "El caudillo ni los jefes de un golpe de Estado, revolución 
Esta revista forma parte del acervo de la Biblioteca Jurídica Virtual del Instituto de Investigaciones Jurídicas de la UNAM

La Comisión IDH aceptó como válida la prohibición a ser electo como presidente a un militar que había participado en la alteración del orden constitucional en Guatemala por asumir el poder después del golpe. En efecto, la condición de inelegibilidad para quienes dirigen movimientos o gobiernos de ruptura del orden constitucional es, a juicio de la Comisión IDH, una norma de defensa común internacional para la consolidación democrática de la región. En las diferentes constituciones de Guatemala, por ejemplo, esta regla prohibitiva aparece desde principios del siglo XX y es mantenida por las distintas reformas. No es sólo pues una tradición constitucional guatemalteca, sino que aparece también en otras Constituciones de varios países centroamericanos en similares términos. Incluso, la raíz común de esa condición de inelegibilidad constituye el Tratado General de Paz y Amistad celebrado en 1923 entre los gobiernos de las Repúblicas de Guatemala, El Salvador, Honduras, Nicaragua y Costa Rica, por el cual las partes contratantes se obligaban a no reconocer a gobiernos de ninguna de las cinco repúblicas que surgieran por golpe de estado o si alguna de las altas autoridades electas hubieran sido jefe o uno de los jefes del golpe de estado o de la revolución.

En consecuencia, la Comisión IDH sostiene que la condición de inelegibilidad establecida por la Constitución de Guatemala es una norma constitucional consuetudinaria de firme tradición en la región centroamericana que tiene como objetivo reafirmar el sistema democrático. Es pues dicha finalidad, proteger al sistema democrático, la que es relevante para justificar la restricción a los derechos de participación política de un quebrantador del orden constitucional, en tanto que prohibir el acceso al poder a los golpistas es una norma "necesaria para la sociedad democrática".

\section{El caso López Mendoza}

El 1o. de septiembre de 2011, la Corte IDH pronunció la Sentencia López Mendoza (2011) mediante la cual declaró la responsabilidad internacional de la República Bolivariana de Venezuela por haber vulnerado el derecho político a ser elegido del ciudadano Leopoldo López Mendoza. ${ }^{58}$ La Corte

armada o movimiento similar, que haya alterado el orden constitucional, ni quienes como consecuencia de tales hechos asuman la Jefatura de Gobierno".

58 La Comisión Interamericana de los Derechos Humanos con base en la denuncia del señor López Mendoza, reclamó la violación a los derechos a “i) ser elegido en elec- 
Esta revista forma parte del acervo de la Biblioteca Jurídica Virtual del Instituto de Investigaciones Jurídicas de la UNAM

IDH, por una parte, dejó sin efectos las sanciones de inhabilitación de tres y seis años para el ejercicio de funciones públicas que le fueron impuestas por la Contraloría General de la República ${ }^{59}$ y ordenó, en especial al Consejo Nacional Electoral, el asegurar que dichas inhabilitaciones no constituyeran impedimento alguno para la postulación del señor López Mendoza como candidato en futuros procesos electorales. El punto central consistió pues en la violación del sufragio pasivo: la sanción de inhabilitación que afecta el derecho a ser electo sólo podía fundarse — según la aplicación de la regla 23.2 del Pacto de San José- en "condena, por un juez competente, en el proceso penal".

Esta Sentencia de la Corte IDH, no obstante, se declaró inejecutable por una resolución inusual de la Sala Constitucional del Tribunal Supremo de Justicia de Venezuela ${ }^{60}$ (en adelante TSJV). En ella se difiere de la aplicación de la "cláusula por condena" porque se estima que la legislación nacional puede establecer sanciones, diferentes a la condena penal, para inhabilitar algunos derechos ciudadanos por actos de corrupción como parte de sus compromisos internacionales de adoptar medidas para el buen gobierno, pero sobre el punto principal el TSJV dice "que el ciudadano Leopoldo López Mendoza goza de los derechos políticos consagrados en la Constitución de la República Bolivariana de Venezuela, por tratarse sólo de una inhabilitación administrativa y no política". Sin duda, la Sentencia del TSJV resulta contradictoria ${ }^{61}$ e implica un desacato claro y expreso al fallo

ciones periódicas auténticas, realizadas por sufragio universal e igual y por voto secreto que garantice la libre expresión de la voluntad de los electores; ii) ...no limitar el ejercicio de los derechos políticos, salvo por sentencia definitiva emitida por un juez competente, previo proceso penal; iii) ... ser oído con las debidas garantías y dentro de un plazo razonable, por un juez o tribunal competente, independiente e imparcial, establecido con anterioridad por la ley, para la determinación de sus derechos y obligaciones; iv) ....ser sancionado por los mismos hechos con base en los cuales ha sido previamente sancionado o absuelto por la autoridad competente, y v) a la protección judicial y a la igualdad ante la ley".

59 Véase artículos 93 y 105 Ley Orgánica de la Contraloría General de la República y del Sistema Nacional de Control Fiscal de 2001.

60 Véase Sentencia de la Sala Constitucional del Tribunal Supremo de Justicia de la República Bolivariana de Venezuela, expediente 11-1130, 17 de octubre de 2011.

${ }^{61}$ El fallo de inejecución del TSJV sostiene, por una parte, que no existe inhabilitación política (privación del sufragio pasivo) porque, entre otras consideraciones, reconoce que dicha sanción, conforme a las leyes venezolanas, sólo opera mediante una condena penal y en el caso sólo se dictó una inhabilitación administrativa; por otro lado, el TSJV se niega a aceptar como válida la solución de la regla 23.2 de la CADH porque sostiene 
Esta revista forma parte del acervo de la Biblioteca Jurídica Virtual del Instituto de Investigaciones Jurídicas de la UNAM

interamericano: el juez venezolano no puede alegar una reinterpretación de normas nacionales e internacionales para desobedecer lo específicamente juzgado por la Corte IDH cuya jurisdicción ha aceptado; ${ }^{62} \sin$ embargo, lo cierto es que el señor López Mendoza podría postularse como candidato presidencial en las elecciones de Venezuela de 2012, ${ }^{63}$ aunque el ejercicio de la función pública — si se extiende la inaplicación del precedente interamericano por parte del TSJV - podría plantear de nuevo el problema de la inhabilitación política: si bien de manera ambigua se reconoce el derecho a postularse como candidato, el TSJV dejó la puerta abierta —en los derechos políticos que enlistó como vigentes no reconoce "el de ejercer el cargo popular" - para una posible interpretación que niegue al señor López Mendoza la posibilidad de ejercer el cargo representativo si es electo. ${ }^{64}$ Es claro pues que en este caso venezolano subyace la polémica sobre el alcance de las inhabilitaciones administrativas en materia de derechos políticos. No me detendré a revisar aquí las cuestiones específicas. Sí me interesa, por el contrario, destacar que en cierta medida algunas consideraciones del TSJV son conducentes — no para inejecutar la Sentencia de la Corte IDH— en

que dicho tratado interamericano no puede prohibir que la legislación nacional pueda establecer sanciones administrativas de inhabilitación para actos de corrupción, pero al final de cuentas la condena de la Corte IDH se refirió exclusivamente a la inhabilitación política. Entonces: si el TSJV sostiene que en ningún momento hay inhabilitación política porque no hay sentencia penal, resulta contradictorio que se niegue a aceptar la decisión de la Corte IDH que señala justamente que el derecho al sufragio pasivo no se puede restringir porque no hay esa condena. El disenso del TSJV es obviamente contradictorio y, por ende, sospechoso en cuanto a su imparcialidad: Hugo Chávez, presidente de Venezuela, había descalificado antes a la Corte IDH (véase El Universal, "Chávez: la Corte Interamericana no vale nada, es un cero a la izquierda", 17 de septiembre de 2011, disponible en: http:// www.eluniversal.com

62 Véase Alerta de la Red Latinoamericana y del Caribe para la Democracia: "Venezuela desacata decisiones de la Corte y la Comisión Interamericana de Derechos Humanos", disponible en: $h t t p: / / w w w$. democracialatinoamerica.org/inicio/alertas

63 Véase http://www.leopoldolopez.com/new/2011/10/18/puedo-y-voy-a-ser-candidato/

64 Esta hipótesis de solución sería de nueva cuenta contradictoria con la Sentencia del TSJV, porque el sufragio pasivo no sólo implica el derecho a postularse sino también a ejercer el cargo popular. Luego entonces, si el TSJV admite que las inhabilitaciones administrativas no tienen efectos en materia política, es claro que si en una nueva controversia niega al señor López Mendoza el derecho político a ejercer el cargo representativo porque considera que no puede ejercer dicha función pública por la vigencia de la inhabilitación administrativa, en realidad estaría asumiendo una posición evidentemente contradictoria y sospechosa: reconoce que el derecho a ser candidato no está restringido, pero si ganara en las urnas el cargo público no podría ejercerlo. 
Esta revista forma parte del acervo de la Biblioteca Jurídica Virtual del Instituto de Investigaciones Jurídicas de la UNAM

cuanto a discutir los efectos de la doctrina López Mendoza en los casos futuros que se relacionen con similares o diferentes supuestos de naturaleza — civil, electoral, administrativa, penal, política, etcétera - sobre privación del sufragio. Para efectos de este trabajo me limitaré, consecuentemente, a describir los hechos y las soluciones del precedente interamericano con el fin de discutir las dos interpretaciones que se pueden desarrollar en el caso mexicano - en especial la suspensión por causa penal-.

¿Cuáles son los hechos relevantes? El 4 de agosto de 2000 Leopoldo López Mendoza fue elegido por voto popular como alcalde del Municipio Chacao y reelegido el 31 de octubre de 2004, desempeñándose en dicho cargo por ocho años, hasta noviembre de 2008. Al finalizar su mandato aspiraba a presentarse como candidato para la Alcaldía del Estado Mayor de Caracas en las elecciones respectivas. Sin embargo, no pudo presentarse como candidato debido a dos sanciones de inhabilitación que le fueron impuestas por el contralor general de la República en el marco de dos procesos administrativos por supuestos actos de corrupción. La primera investigación de la que fue objeto el señor López Mendoza se relacionaba con hechos ocurridos mientras desempeñaba un cargo en la empresa Petróleos de Venezuela S. A., antes de ser alcalde. La segunda se circunscribió a hechos en el marco de sus actuaciones como alcalde. ${ }^{65}$ El punto central del caso, según la Corte IDH, radica en que las sanciones de inhabilitación impuestas al señor López Mendoza por decisión de un órgano administrativo le impidieron registrar su candidatura para cargos de elección popular. La Comisión IDH alegó, por su parte, que la sanción de inhabilitación para ejercer cargos públicos restringió de manera indebida los derechos políticos del señor López Mendoza, ya que fue impuesta por un procedimiento administrativo y no mediante "condena, por juez competente, en proceso penal" como lo establece el artículo 23.2 de la Convención $\mathrm{ADH}$, de tal forma que "es únicamente un tribunal judicial en un proceso penal el que puede restringir el derecho" y "cualquier restricción que se derive de dicho proceso deberá guardar estricto respeto a las garantías penales". ${ }^{66}$

65 El detalle de los hechos puede verse en la sentencia interamericana López Mendoza vs. Venezuela (2011).

${ }^{66}$ A la Corte IDH le correspondió determinar si las sanciones de inhabilitación impuestas al señor López Mendoza por decisión de un órgano administrativo y la consiguiente imposibilidad de que registrara su candidatura para cargos de elección popular, eran o no compatibles con la CADH. La Corte, por tanto, no se pronunció sobre la interpretación del derecho interno venezolano ni tampoco sobre las cuestiones de derecho 
Esta revista forma parte del acervo de la Biblioteca Jurídica Virtual del Instituto de Investigaciones Jurídicas de la UNAM

Pues bien, la Corte IDH orientó su decisión a partir de tres premisas:

- A1. El "argumento de la condena penal". En primer lugar, la Corte IDH señala que "el artículo 23.2 de la Convención Americana determina cuáles son las causales que permiten restringir los derechos reconocidos en el artículo 23.1, así como, en su caso, los requisitos que deben cumplirse para que proceda tal restricción". Luego entonces: "una restricción impuesta por vía de sanción, debería tratarse de una condena, por juez competente, en proceso penal". En el caso López Mendoza ninguno de esos requisitos se cumplió:

el órgano que impuso dichas sanciones no era un "juez competente", no hubo "condena" y las sanciones no se aplicaron como resultado de un "proceso penal", en el que tendrían que haberse respetado las garantías judiciales consagradas en el artículo 8o. de la Convención Americana.

- A2. E1 "argumento de motivar en forma concreta y autónoma la proporcionalidad". ${ }^{67}$ En segundo término, la Corte IDH sostiene la omisión del deber de motivación como requisito para restringir el sufragio; es decir, la autoridad nacional tenía que "desarrollar razones y fundamentos específicos sobre la gravedad y entidad de la falta supuestamente cometida por el señor López Mendoza y sobre

comparado que se alegaron, en tanto que sostuvo que si "en el futuro se presentara ante la Corte algún caso en que se haya aplicado una de las normas nacionales sería entonces procedente analizarlas a la luz de las disposiciones de la Convención Americana".

${ }_{67}$ Este argumento (A2) — como el de la ley predecible (A3) — adolece de una contradicción. Si la Corte IDH había dicho que la privación del sufragio era incompatible con la cláusula por condena en virtud de que no había sido dictada la sentencia por juez competente en el proceso penal, resulta absurdo exigirle a la autoridad administrativa el deber de motivar la proporcionalidad de la restricción e imponer en un plazo cierto, razonable y previsible la sanción, en tanto que, al final y al cabo, la Contraloría era una autoridad incompetente conforme al primer argumento (A1). Dicho de otra forma: una autoridad (in)competente para restringir un derecho político no tiene el deber de motivar la restricción porque justamente no le corresponde restringirlo menos aún motivarlo. En todo caso, el deber de motivar se le reprocharía al juez competente en el proceso penal. Es claro, empero, que el argumento sí es válido no obstante la imprecisión competencial, sobre todo porque resulta una línea relevante para reconstruir la doctrina interamericana que debe seguirse para los casos futuros; es decir, las autoridades que les competan ordenar las restricciones del sufragio por vía de sanción tienen el deber de motivar. Esto es lo importante. 
Esta revista forma parte del acervo de la Biblioteca Jurídica Virtual del Instituto de Investigaciones Jurídicas de la UNAM

la proporcionalidad de la sanción adoptada". La motivación adecuada es una condición para restringir los derechos políticos porque permite verificar una evaluación concreta y autónoma, a fin de evitar que una sanción de inhabilitación de tipo administrativo para ejercer la función pública opere en forma casi automática en el derecho al sufragio pasivo.

- A3. El "argumento de la ley predecible". Finalmente, la Corte IDH considera —a partir de la doctrina europea — ${ }^{68}$ que en el marco de las garantías del artículo 8.1 de la Convención Americana se debe salvaguardar la seguridad jurídica sobre el momento en el que se puede imponer una restricción del sufragio. Reprocha, por tanto, que la ley venezolana que se aplicó para inhabilitar al señor López Mendoza no tenga un "plazo cierto, previsible y razonable" para imponer la sanción, pues ello "puede dar lugar a un ejercicio arbitrario de la discrecionalidad a través de sanciones aplicadas en un momento totalmente inesperado para la persona que ya fue declarada responsable previamente". Es decir: el poder de imponer una sanción accesoria por un ilícito no puede mantenerse en suspenso, a la discreción de la autoridad cuando así lo considere e incluso después de transcurrido algunos años, so riesgo de generar, como lo denunció la Comisión de IDH, la "inseguridad jurídica, arbitrariedad y falta de transparencia".

Estas tres líneas argumentativas conforman el núcleo esencial de la doctrina López Mendoza. Son relevantes, a mi juicio, para reconstruir los conceptos generales que pueden orientar las soluciones concretas según el sistema legal de restricción del sufragio por violación a la ley — penal, política, administrativa, electoral, de partidos, etcétera-. La fórmula López Mendoza, por tanto, plantea que en principio la privación del sufragio por vía de sanción sólo puede imponerse:

68 La Corte IDH dice: "la Corte Europea ha establecido que la norma respectiva debe ser: i) adecuadamente accesible, ii) suficientemente precisa, y iii) previsible. Respecto a este último aspecto, la Corte Europea utiliza el denominado 'test de previsibilidad', el cual tiene en cuenta tres criterios para determinar si una norma es lo suficientemente previsible, a saber: i) el contexto de la norma bajo análisis; ii) el ámbito de aplicación para el que fue creado la norma, y iii) el estatus de las personas a quien está dirigida la norma". 
Esta revista forma parte del acervo de la Biblioteca Jurídica Virtual del Instituto de Investigaciones Jurídicas de la UNAM

a) previo juicio penal seguido con todas las formalidades esenciales en el que el juez competente imponga como pena la suspensión de los derechos políticos (condena penal);

b) que se motive en forma autónoma y concreta la proporcionalidad de la sanción; $y$,

c) que la imposición de la restricción esté prevista en ley cierta, razonable y previsible.

\section{REFLEXIONES FINALES}

Una distinción como punto de partida. No es lo mismo justificar la privación del derecho a votar, que el de ser votado. Los fines, perfiles y dimensiones del problema son distintos.

Por ejemplo: no parece representar, a primera impresión, riesgo grave para la democracia que un delincuente vote en las elecciones. Su decisión, en principio, no es la única que configura la representación política; la conducta ilegal sólo podría estar limitada en la medida en que merezca razonablemente la suspensión del sufragio activo por la afectación grave de la libertad de decidir que, además, sea relevante para el resultado electoral (coacción o presión del voto). Por el contrario, el que una persona relacionada con un golpe de Estado, con un grupo terrorista o fundamentalista tenga la oportunidad de ser electo sí, en principio, puede afectar la libertad de los demás por el peligro electoral que representa si como representante público puede llegar a tomar decisiones que beneficien al grupo golpista o terrorista.

La experiencia de las candidaturas golpistas en los sistemas americano y europeo de derechos humanos, respectivamente, plantean un estándar común para limitar candidaturas que suponen un daño o peligro real para el sistema político: puede llegar a ser militante a la cláusula del principio de sociedad democrática, pero con una forma distinta de aplicar la regla por sentencia de condena, sea de manera categórica o proporcional. Veamos:

En Ríos Montt queda claro que la aplicación de la muerte ciudadana fue categórica: la Comisión IDH no Exigió, como la Corte IDH en el caso López Mendoza, la existencia de una condena penal previa para limitar el sufragio pasivo. Bastó la prueba del golpista para justificar la restricción del sufragio por un principio de seguridad del orden constitucional. La lectura europea. Por el contrario, Ždanoka aunque se asimila la solución en cuanto no exige la condena penal previa de la golpista, el Tribunal EDH 
Esta revista forma parte del acervo de la Biblioteca Jurídica Virtual del Instituto de Investigaciones Jurídicas de la UNAM

realiza un mayor juicio de proporcionalidad para explicar la necesidad de la restricción, de tal suerte que no es categórica la aplicación de la cláusula de la muerte ciudadana sino que requiere justificarse de manera motivada.

En los casos Sobaci y López Mendoza, de igual forma, existe una solución similar pero una manera diferente de aplicar la justificación de la restricción del sufragio pasivo. En el primer caso se realiza un juicio de explicar la proporcionalidad de la medida que pretende limitar el sufragio con motivo de la vinculación a un partido ilegalizado (conducta antidemocrática), mientras que en el segundo caso no es necesario justificar si el hecho motivo de la restricción es proporcional (falta administrativa), porque de manera categórica se aplica la categoría de condena penal para no limitar el sufragio pasivo aun cuando en Ríos Montt eso fue innecesario.

¿Cuál es la manera correcta de resolver estos problemas? En América Latina ${ }^{69}$ y Europa $^{70}$ se establecen restricciones legales al derecho a ser electo por los riesgos que representan las candidaturas de lesa humanidad, golpistas, terroristas, fundamentalistas, racistas o cualquier otra categoría peligrosa. Estos son los miedos electorales a considerar: los peligros para la voluntad popular si el criminal vota o el que el terrorista, el dictador o el fundamentalista gobierne. En efecto, el miedo a construir una voluntad general que represente riesgos graves a los fines de la democracia constituye la razón principal de la privación del sufragio. ¿Es válido regular estos miedos? Todo depende de la "razón de la ley". Como todos los miedos políticos tienen una explicación contextual, una justificación conceptual y una finalidad a motivar. Pueden ser aceptables o no. La gran parte de los miedos electorales se explican por el contexto político: los golpistas de Centroamérica por la historia de golpes de Estado en esa región; los proterroritas de España por la lucha antiterrorista; los fundamentalistas de Turquía por los ataques de algunos partidos al Estado laico; los dictadores de Argentina por los crímenes de lesa humanidad; los mafiosos en Italia por la historia de la Cosa Nostra. En fin, los contextos históricos tienen narraciones problemáticas que deben explicarse de manera historicista, contractualista, republicana,

${ }^{69}$ En Argentina, la justicia transicional promueve la tesis de que los dictadores acusados por los crímenes de lesa humanidad no deben gobernar. ¿Por qué? No sólo por razones retributivas sino también para evitar la impunidad de todos aquellos que se siguen beneficiando del cargo representativo para no ser juzgados por los crímenes del pasado.

70 En España, las listas contaminadas representan el riesgo de defraudar la ilegalización del partido: pueden llegar a gobernar las personas que están vinculadas con el entramado terrorista. 
meritocrática o militante para entender la finalidad a perseguir: evitar males electorales que constituyan riesgos graves a la conformación libre, auténtica y funcional del gobierno representativo.

El "miedo electoral", por tanto, es un tipo de miedo político que constituye, a mi juicio, la categoría principal sobre la cual las leyes de privación del sufragio explican su razón de ser: la conducta que quebranta el pacto representa una serie de riesgos, reales e imaginarios (posibles e imposibles), para los fines de la democracia electoral. El "miedo electoral", por ende, implica el riesgo grave que el abuso de la libertad política puede representar para la renovación periódica, conformación libre y funcionalidad adecuada del gobierno representativo. Es la naturaleza preventiva de la ley del miedo electoral: antes de que abusen de la libertad de gobernar, a los quebrantadores del pacto se les prohíbe gobernar.

Ahora bien, el problema toral — común en todas las leyes de miedoradica en que las diferentes percepciones del miedo pueden ser aceptables (o no) para ser reguladas. Los individuos, sin duda, sentimos miedo en ocasiones cuando en realidad no deberíamos tenerlo; e incluso no tenemos miedo cuando sí deberíamos tenerlo. La regulación legal de los miedos electorales producen mandatos prohibitivos de la libertad política que, según los peligros reales o imaginarios a los fines de la democracia, pueden llegar a constituir pautas de precaución afortunadas, desafortunadas y hasta peligrosas para la comunidad liberal. Por tanto, las creencias sobre las cuales se basa el miedo electoral pueden estar justificadas o no, por lo que el reto es construir regulaciones estrictas que permitan evaluar de manera racional que los daños y riesgos a prevenir en la democracia, explican suficientemente el sacrificio de la libertad electoral mediante la privación del sufragio. En caso contrario, el mandato prohibitivo de la ley del miedo electoral se convertirá paradójicamente en un peligro para la libertad en la sociedad democrática: lo que se pretende evitar (riesgos a la conformación libre de la voluntad popular), en realidad se provocaría con la propia privación inusual, desproporcional o excesiva del sufragio (daños a la conformación libre de la voluntad popular).

La clave es encontrar las causas que originan el abuso de la libertad que hacen peligrar a la democracia para configurar las razones legales que motivarían la privación del sufragio. La paradoja de la tesis es simple. Los quebrantadores del pacto (lawbreakers) no deben ser los legisladores (lawmakers), pero no todo lawbreaker merece la privación del sufragio. 
Esta revista forma parte del acervo de la Biblioteca Jurídica Virtual del Instituto de Investigaciones Jurídicas de la UNAM

La contradicción, por ende, resulta aparente. En realidad sólo un tipo de lawbreaker (el que ofende de manera grave a la democracia), es el que no debe ser lawmaker en la sociedad libre. Entonces: ¿cómo debe responder un gobierno democrático ante el miedo electoral? ¿Se puede defender la democracia excluyendo a sus enemigos? ¿Qué tipo de miedos electorales son intolerables? ¿Bajo qué condiciones se puede limitar la ciudadanía peligrosa? ¿Qué es el riesgo electoral? ¿Cómo podemos medir la certeza, posibilidad o probabilidad de un riesgo para la democracia? Estas cuestiones plantean dos ámbitos: 1) el conceptual, y 2) el instrumental.

1. El "concepto del miedo electoral". ¿Qué tipos de peligro electoral se deben prohibir mediante una ley del miedo?, ¿cómo constatar y evaluar esos riesgos inaceptables? La primera pregunta implica el problema del concepto y fundamento de la libertad electoral a limitar a partir de un juicio de peligrosidad. Las concepciones historicistas, contractualistas, republicanas, meritocráticas y militantes, por otra parte, son los puntos de partida para aceptar o rechazar los límites que se pueden imponer a las personas que disienten o pretenden destruir la idea misma de la democracia.

2. El "test del peligro electoral". La segunda cuestión sobre el riesgo electoral plantea un juicio de prognosis, la evaluación de la conducta dañina o posible ejecución de los actos idóneos y unívocos (del peligroso electoralmente), cuya actitud y aptitud pone en estado de riesgo a la democracia. El punto a discutir radica en las diferentes concepciones y pruebas del juicio de peligrosidad, riesgo abstracto o concreto: según el concepto de la ley del miedo electoral, se puede llegar a excesos de restringir la libertad electoral por daños o riesgos inidóneos, imposibles o inexistentes.

El desarrollo de la tesis central consiste pues en describir las diversas razones, formas y condiciones que las democracias actuales emplean para establecer los límites a la "ciudadanía política" por el quebrantamiento de la ley. La explicación contemporánea de la privación del sufragio pasivo consiste pues en la idea de reformular el concepto tradicional de la restricción absoluta y categórica (blanket ban) por una concepción proporcional. ${ }^{71}$ El punto de llegada, por tanto, es la configuración de la "muerte

71 La versión proporcional afirma que toda persona condenada puede tener privada su libertad electoral en forma razonable según el delito y las circunstancias de ejecución: 
Esta revista forma parte del acervo de la Biblioteca Jurídica Virtual del Instituto de Investigaciones Jurídicas de la UNAM

ciudadana" como garantía del derecho a las elecciones libres que tiene por objeto conformar de manera legítima el gobierno representativo. Esto es: puede ser posible y válido que se prive del derecho a elegir y a ser electo, según cada contexto y de manera proporcional, para prevenir los fraudes electorales, configurar de manera auténtica el sufragio, garantizar la seguridad del Estado o la conformación libre de la representación política; en fin, para proteger ciertos bienes jurídicos relevantes que se vulneran por ciertos delitos o conductas antidemocráticas que hacen necesarias y útiles este tipo de medidas restrictivas que aseguran los fines de la democracia representativa. El problema, por consiguiente, consistirá en construir las fórmulas correctas —o más justificadas - que permitan determinar de manera específica, excepcional y temporal la restricción proporcional a los derechos electorales por causa penal o antidemocrática, la sanción más fuerte que se puede imponer a la ciudadanía política.

Esta postura restrictiva no está exenta de críticas, deficiencias e insuficiencias, pero pretende hacer coexistir en armonía conceptos en pugna que de otra manera son irreconciliables. Obliga a reconocer, por ende, que en una democracia constitucional sí es posible que el derecho utilice la razón legal para limitar la libertad política de ciertas personas que ofenden el pacto, pero al mismo tiempo es necesario garantizar, como consecuencia obvia y necesaria, que la política de la restricción del sufragio deba ser explicada con hechos, normas y valores plausibles bajo los estándares del Estado constitucional de derecho. El quid está desde luego en formular el concepto correcto —o más justificado posible — que de manera excepcional justifique la limitación particularista del sufragio universal. Ese concepto, de acuerdo con la tesis a desarrollar, es la "ley del miedo electoral".

\section{TABLA DE CASOS}

Tribunal EDH (Estrasburgo)

Adamsons vs. Latvia (2008), 24 de junio de 2008. Hirst vs. The United Kingdom (2006), 6 de octubre de 2005. cia, derecho político a restringir, condición de prisión o de libertad provisional, etcétera. 
Esta revista forma parte del acervo de la Biblioteca Jurídica Virtual del Instituto de Investigaciones Jurídicas de la UNAM

Labita vs. Italy, (2004), 1o. de julio de 2004.

Refah Partisi and others vs. Turkey, (2001), 21 de julio de 2001.

Sobaci vs. Turkey, (2007), 9 de noviembre de 2007.

Vito Sante Santero vs. Italy, (2000), 6 de abril de 2000.

Ždanoka vs. Latvia, (2006), 16 de marzo de 2006.

\section{Comisión IDH y Corte IDH}

Ríos Montt (1993), Comisión IDH, Informe núm. 30/93, caso 10.804, Guatemala, 12 de octubre de 1993.

López Mendoza (2011), Corte IDH, Sentencia de 1o. de septiembre de 2011.

Fecha de recepción: 2 de marzo de 2016.

Fecha de dictamen: 17 de mayo de 2016. 